Anita Wincencjusz-Patyna

https://doi.org.10.26881/ae.2018.15.07

ORCID: 0000-0001-5473-5721

Akademia Sztuk Pięknych im. Eugeniusza Gepperta we Wrocławiu

a.wincencjusz@asp.wroc.pl

\title{
Jak książkę obrazkową postrzega historyczka sztuki? Oczywistości i wątpliwości
}

W dyspucie akademickiej, refleksji oraz badaniach nauki przyrodnicze wydają się mieć zdecydowaną przewagę nad humanistycznymi ze względu na możliwość przeprowadzania doświadczeń, dowodów, obserwacji, a zatem weryfikowalność tych pierwszych. Humanistyka z kolei wygrywa ze sztukami pięknymi, które bronią się przed kodyfikacjami, wymykają się obiektywnym analizom i ocenom. Oczywistością jest, że nie można jednak w związku z tym zarzucać trudu zajmowania się nieuchwytnymi zjawiskami z obszaru nauk nieścisłych, jak chociażby książką obrazkową. Wątpliwości może natomiast budzić kierunek, w którym badania książki obrazkowej niejednokrotnie podążają. W każdym razie badania te, zdarza się, budzą moje wątpliwości, o czym poniżej.

Long Room w Starej Bibliotece Trinity College w Dublinie to niezwykłej urody 65-metrowe wnętrze, które powstawało etapami w latach 1712-1732, a od 1860 roku mogło poszczycić się drugą górną galerią oraz bardzo charakterystycznym sklepieniem beczkowym. Architektem tego budynku był Thomas Burgh. Wnętrze Long Room widziane z pewnej perspektywy na swój sposób ilustruje moje podejście do interesującej mnie tutaj tematyki. Ta olbrzymia sala to biblioteka. Dubliński Long Room mieści około 200 tys. najstarszych i najbardziej wartościowych woluminów z irlandzkiej kolekcji, a historyk sztuki w pierwszej kolejności widzi architekturę zabytkowego wnętrza, która uwodzi swoim kunsztem, rytmem, zgodnością formy z funkcją, zastosowanymi materiałami.

Oprócz tego w Starej Bibliotece Trinity College od 1654 roku przechowuje się słynny Ewangeliarz św. Kolumby - znany powszechnie jako Book of Kells - Księga z Kells. 360 folio - kart welinowych stanowi arcydzieło wczesnośredniowiecznego iluminatorstwa. Historycy sztuki, nie tylko specjaliści w zakresie mediewalnego miniatorstwa, zgodni są co do tego, że funkcjonalność księgi zdecydowanie ustąpiła przed estetyką manuskryptu. Przesunięcia wersów, pozostawione błędy w zapisie, 
a jednocześnie dbałość o przejrzystość kompozycji stron z iluminacjami i ornamentacją świadczą o tym, która $\mathrm{z}$ warstw komunikacyjnych była dla twórców manuskryptu priorytetowa. To bogactwo oraz ilość wyobrażeń wypełniających Księgę z Kells czynią z niej też właściwie prototyp książki obrazkowej, jeśli pójść za współczesną wykładnią, że książki takie powstają nie tylko z myślą o odbiorcy dziecięcym. Widoczna w celtyckim arcydziele predylekcja do warstwy wizualnej książki także jest mi bliska, z niej wynikają moje następne przemyślenia.

Oczywistość otwierająca ten wywód to zatem przyznanie się, że jako historyczkę sztuki zawsze na pierwszym miejscu interesuje mnie sztuka. Oczywistość druga to fakt, że dowolny obraz w książce (czy najszerzej rozumiana ilustracja [łac. illustratio - unaocznienie]) - o ile powstał jako do tej książki przeznaczony, jest przykładem nieautonomicznego dzieła sztuki. Ta zależność obrazu od tekstu, która sama podlega gradacji od ścisłych powiązań (demonstracji materii zawartej w utworze literackim), przez indywidualną interpretację artystyczną, po bardzo luźne związki (odległe skojarzenia również o naturze raczej indywidualnej), może mieć też różny charakter - ogólny i specyficzny.

Podstawowa zależność to właśnie najbardziej oczywista w przypadku ilustracji obrazu od materii słowa. Jest też wzajemna korelacja obrazów w ramach cyklu, czyli w zestawie ilustracji zaprojektowanych do konkretnego utworu (chociażby aspekt powtarzalności bohaterów, szczegółów miejsca i czasu akcji, użytych rekwizytów itd.). Można by je określić zależnościami ogólnymi, występującymi we wszystkich książkach ilustrowanych.

Są też relacje specyficzne, mogące wynikać z czasu i miejsca powstania prac (określona stylistyka, tendencja artystyczna, moda, maniera właściwa dla konkretnych okoliczności), z indywidualnego stylu artysty, wybranej przez niego konwencji, przestrzegania lub nie zasady decorum oraz wielu jeszcze innych czynników.

Książka obrazkowa jest z mojej perspektywy badawczej - historyczki sztuki, która od ponad piętnastu lat zajmuje się ilustracją książkową - po prostu przypadkiem książki ilustrowanej, uściślić można by tutaj - bogato ilustrowanej, a nawet ryzykując podejrzaną obecnie nomenklaturę - książki ilustrowanej totalnie.

Zgadzam się z definicją zaproponowaną przez Kristin Hallberg już bez mała czterdzieści lat temu (Hallberg 1982: 163-168) podkreślającą ścisłą zależność, a nawet nierozerwalność wprowadzonego przez nią pojęcia ikonotekstu, które zakłada niemożność osobnej egzystencji czy lektury warstwy werbalnej i warstwy wizualnej danej książki (zob. Hallberg 2017: 52). Tekst książki ilustrowanej nieobrazkowej da się czytać bez najmniejszej straty sensu, nawet gdy pozbawieni zostaniemy możliwości obcowania z oryginalną ikonografią (to na przykład czytanie przez kogoś innego klasyczny w relacji dorosły czytający dziecku; akt wandalizmu książkowego - co niestety zdarza się w egzemplarzach bibliotecznych - na przykład wycięte ilustracje, ilustracje przemalowane, zwłaszcza partie twarzy bohaterów; świadomość istnienia nieilustrowanych wydań tego samego tytułu itd.). Z kolei towarzyszące książce obrazy-ilustracje widziane poza woluminem (na przykład wystawa oryginałów prac, katalog z ekspozycji, album twórczości danego artysty) mogą funkcjonować jak 
samodzielne dzieła sztuki, tyle że przy mniej rozpoznawalnych tytułach jesteśmy pozbawieni podstawy interpretacyjnej, która w tym wypadku wiele wnosi, choć nie uniemożliwia podstawowej analizy formalnej. Można by nawet zaryzykować propozycję czegoś w rodzaju „testu audiobooka” - jeżeli słyszany tekst sprawia wrażenie kompletnego, nie mamy do czynienia z książką obrazkową - dla niej jedynym, acz niedoskonałym ratunkiem jest szczegółowa i umiejętna audiodeskrypcja.

Ikonotekst wydaje mi się też na swój sposób bardziej precyzyjny niż niezwykle pojemne - jak się okazuje - pojęcie „książka obrazkowa”. Sami badacze, analizując w swych opracowaniach przykłady książek uznanych za obrazkowe, dość swobodnie żonglują publikacjami, wśród których pojawia się niemało książek jednak po prostu ilustrowanych. Takimi łatwymi do podważenia przypadkami mogłyby tu stać się książki, które wykorzystując jeden i ten sam (z reguły krótki) tekst - najczęściej wierszowany, ukazały się $\mathrm{w}$ różnym opracowaniu graficznym, $\mathrm{z}$ ilustracjami autorstwa różnych artystów. Niech będzie to na przykład Lokomotywa Juliana Tuwima w opracowaniu Jana Lewitta i Jerzego Hima, Jana Marcina Szancera, Jana Lenicy czy Małgorzaty Gurowskiej, by wymienić te dobrze znane i prezentujące wysoki poziom artystyczny, lub Tańcowała igła $z$ nitka Jana Brzechwy w wersji plastycznej Franciszki Themerson, Stanisława Zamecznika czy Bohdana Butenki. W ogóle trudno utwory poetyckie postrzegać jako niesamowystarczalne w interesującym nas aspekcie. Choć warto jednak nadmienić, że czasem powstawały pod wpływem inspiracji obrazami (znamy tego liczne przykłady w liryce dla dorosłych; można tu akurat wspomnieć o Pawich wierszach - Tadeusz Kubiak stworzył je po tym, jak zobaczył w teczce wydawcy akwarele Józefa Wilkonia).

Spójrzmy zatem choćby na tomik Idzie kot Stanisława Szydłowskiego w opracowaniu graficznym Stanisława Zamecznika z wykorzystaniem fotografii Jana Styczyńskiego (Szydłowski 1968). Ta książka jest niewielkim zbiorem krótkich rymowanych, nieco absurdalnych wierszy o naturze kota domowego. Wiersze te przeczytane czy wysłuchane bez akompaniamentu warstwy wizualnej nic nie tracą ze swojego przekazu. O ileż jednak bardziej dowcipne, surrealistyczne, wyrafinowane stają się dzięki eleganckim czarno-białym zdjęciom, czasami zabarwionym tu i ówdzie monochromatyczną tonacją błękitną lub pomarańczową, oraz sporadycznie dodanym rysunkom autora szaty graficznej. Znaczenia nabiera też dynamika układu typograficznego, ale przede wszystkim zastosowanie całej gamy środków formalnych: multiplikacji, zmiany skali, różnorodności ujęć kompozycyjnych, alternacji, czyli układu przemiennego motywów - od kompozycji otwartej i szerokiego planu po zbliżenie, tzw. duży detal (odwołując się do najtrafniejszej w tym wypadku terminologii filmowej). Większość fotografii, nawet podanych w takim opracowaniu graficznym, mogłaby się znaleźć w popularnonaukowym opracowaniu dotyczącym osobników z gatunku felis catus albo wydawnictwie poradnikowym dla hodowców amatorów mruczków. Może jedynie lampa naftowa z kocimi oczami odebrałaby książkom tym nieco powagi. Czyli zarówno tekst, jak i grafika mogą $\mathrm{w}$ tym przypadku istnieć niezależnie. $\mathrm{Z}$ drugiej strony obie warstwy wzajemnie się 
uzupełniają, komentują, akcentują, przynosząc spójną całość wizualno-werbalną. Pozostawiam zatem otwartym pytanie - czy Idzie kot jest książką obrazkową czy nie?

Oczywistością, choć warto zauważyć, że wyrażoną explicite dopiero w nowszych badaniach nad książką obrazkową, wydaje się stwierdzenie, że książka obrazkowa jest for $\mathrm{m}$ ą s z t u k i" [wyróżnienie - A.W.P.]. Wystarczy odwołać się tu do liczącego już co prawda kilkanaście lat (2001) opracowania Marii Nikolajevej i Carole Scott How Picturebooks Work (Nikolajeva, Scott 2006: 1). Wątpliwość odczuwam natomiast, wczytując się w otwierające tę książkę zdanie: „Wyjątkowy (unikalny) charakter książek obrazkowych jako formy sztuki opiera się na połączeniu dwóch poziomów komunikacji - wizualnej i werbalnej" (ibidem: 1). Otóż przykładów ze świata sztuki na przemyślane, celowe łączenie tych dwóch modi - słowa i obrazu - znajdziemy niemało, co podważa sugerowaną przez autorki wyjątkowość na tym polu książki obrazkowej. Przypomnijmy tu starożytne stele, znaczną część średniowiecznych nagrobków typu transi, przywołane przeze mnie wcześniej miniatorstwo, Tkaninę z Bayeux - datowane na około 1070 rok mierzące ponad $70 \mathrm{~m}$ płótno zawierające opowieść, na którą składa się 75 scen i łacińskich tituli, czyli inskrypcji objaśniających relacje między setkami postaci - epitafia, może przede wszystkim zaś barokową emblematykę, czyli sztukę kompozycji obrazowo-literackich uwypuklającą związki sentencji z imago, siedemnastowieczne cykle graficzne Williama Hogartha i angielską satyrę polityczną, komiks wreszcie, by wymienić tylko niektóre, ale jakże wyraziste przejawy werbalno-wizualnej twórczości na przestrzeni wieków.

Wątpliwości - przynajmniej moje - budzi fakt, że chociaż w How Picturebooks Work książkę obrazkową rozpoznano jako formę sztuki, to nadal jest ona przedmiotem badań głównie literaturoznawców, pedagogów czy bibliologów, którzy niejako $\mathrm{z}$ natury swojej dyscypliny badają w pierwszej kolejności (a czasem prawie wyłącznie) odpowiednio:

- jej warstwę literacką - werbalną (literaturoznawcy),

- jej rolę edukacyjną - poznawczą (pedagodzy),

- jej funkcję jako nośnika treści i społecznego narzędzia kultury, a także jej materialność jako specyficznie ukształtowanego obiektu (bibliolodzy).

$\mathrm{Na}$ drugim, a nawet dalszym miejscu, badacze ci stawiają warstwę wizualną. Nierzadko, niestety, poświęcając jej minimalną część swoich wypowiedzi.

Nikolajeva i Scott przedstawiają przegląd tych tendencji badawczych na stronach 2-6 swojego wstępu. A ja przyznaję w tym miejscu, że najbliższe jest mi stanowisko i perspektywa badawcza Josepha Schwarcza, zaprezentowane w jego pionierskim, też już mającym swoje lata opracowaniu Ways of the Illustrator. Visual Communication in Children's Literature (Schwarcz 1982), ponieważ to właśnie strona wizualna książek obrazkowych jest dla niego priorytetowa.

Jeszcze inną oczywistością jest fakt, że z książek z dzieciństwa silnym, szybkim impulsem zostaje utrwalone w pamięci małego czytelnika najpierw obraz, a potem tekst. I mam tu już na myśli sytuację lektury samodzielnej, kiedy obcuje się z materią słowa i obrazu osobiście, a co ważne - równolegle. Dramatyzm lub liryzm, humor lub przerażenie baśni Andersena odcisnęły się w mojej pamięci przede wszystkim 
za sprawą ilustracji Jana Marcina Szancera (Andersen 1959) i nieco później Janusza Stannego (1975), choć naturalnie doprecyzowane, „dopowiedziane” tekstem wielkiego Duńczyka.

Porównanie zestawu dwóch ilustracji do baśni Słowik i Dzielny ołowiany żołnierz pokazuje też coś jeszcze. O ile w przypadku Szancera możemy mówić o dekoracyjności ilustracji, o jej funkcji demonstracyjnej i podnoszącej atrakcyjność tego konkretnego wydania wyboru baśni pomyślanego dla młodych czytelników, zwłaszcza dzięki ich bajkowości, liryzmowi, ale też świadomemu żonglowaniu staroświecką stylistyką rokokową, o tyle w przypadku propozycji Stannego nie mamy już do czynienia ze sprowadzeniem obrazu do funkcji reprezentacji tekstu. Metafora, atmosfera niepokoju i niedopowiedzenia, chwyty rodem z surrealizmu - zagadkowość, operowanie kontrastem, przeskalowania, deformacja zderzona $\mathrm{z}$ hiperrealizmem czynią z tych ilustracji mistrzowskie autorskie interpretacje niejednokrotnie znacząco odchodzące od oryginalnego tekstu. Obrazy te stają się więc czymś więcej niż po prostu ilustracją, ale omawiany tu zbiór baśni (tym razem adresowany do raczej starszych czytelników) nie stał się przez to książką obrazkową, nadal jest klasyczną publikacją ilustrowaną.

Oczywistością wydaje się, że dość blisko ideału ikonotekstu jesteśmy w przypadku książek autorskich, w których za obie warstwy - wizualną i werbalną - odpowiada jedna osoba. Beatrix Potter, Maurice Sendak, Anthony Browne, Babette Cole, Anne Brouillard, Tomi Ungerer, a na naszym podwórku wspomniany przed chwilą Janusz Stanny, Paweł Pawlak czy Iwona Chmielewska. Intuicyjnie czujemy, że proces powstawania obu warstw przebiegał naprzemiennie, równolegle, nawzajem się doganiając, uzupełniając już istniejące, zapewniając tę nierozerwalność, o którą zda się - idzie.

I tu znów wątpliwość. Czy faktycznie opowieść o Piotrusiu Króliku staje się niekompletna, niezrozumiała, jeśli nie widzimy uroczych akwarel autorstwa Beatrix Potter? To, że traci na urodzie - niewątpliwie. Ale czy same obrazy nie bronią się od dawna, stając się samowystarczalną machiną komercyjnie wykorzystującą motywy animalistyczne na porcelanie, tkaninach, ubraniach, parasolkach, pudełkach metalowych, papeteriach, zabawkach itd.?

Jeszcze innym dowodem jest jedna $\mathrm{z}$ opowieści Potter znana w Polsce jako Krawiec i jego kot lub Krawiec $z$ Gloucester. Wielbiciele dokonań autorki mogli się poczuć poniekąd zdradzeni, a może nawet oszukani, kiedy Nasza Księgarnia, dość odważnie, wydała Krawca i jego kota z ilustracjami innego artysty - Antoniego Boratyńskiego (Potter 1969). Oficyna ta niechcący (i zupełnie nieświadomie) wykazała, że nie jest to książka obrazkowa w wąskim rozumieniu, czyli dzieło kompletne, w którym tekst nie może istnieć bez obrazów, a obrazy stają się nieczytelne bez towarzyszącego im tekstu. Oryginały akwarel namalowane około 1902 roku przez Beatrix Potter, a znajdujące się w zbiorach Tate Gallery, dodatkowo podkreślają, że te niewielkie w skali $(11 \times 9 \mathrm{~cm})$ kompozycje Potter doskonale bronią się bez jej tekstu. Na marginesie zresztą warto zaznaczyć, że historię krawca z Gloucester 
autorka usłyszała w hrabstwie na południu Anglii, a potem „skroiła” ją wedle własnego upodobania.

Przykłady książek obrazkowych, które właściwie są książkami bogato ilustrowanymi, co nieodmiennie cieszy oko czytelnika, a w jeszcze większym stopniu badacza grafiki książkowej, można by niewątpliwie mnożyć. Może warto jednak spojrzeć na to jeszcze inaczej.

Od Pawła Pawlaka - wybitnego polskiego twórcy ilustracji książkowych i książek obrazkowych, w tym autorskich, usłyszałam kiedyś, że definicje [na polu książki ilustrowanej/obrazkowej/książki z obrazkami - A.W.P.] są po to, by się im wymykać. Artysta przyznał też, że nigdy nie zastanawia się, w jakiego typu książkę będzie w najbliższym czasie zaangażowany. Kiedy z kimś pracuje, czuje się odpowiedzialny za stronę wizualną publikacji. Docenia komfort pracy „przez biurko” i możliwości nieustannych konsultacji, kiedy współtworzy książki z żoną Ewą Kozyrą-Pawlak (Korek, Smutna i mądra bajka o przygodach Zająca Grajka z tekstami Kozyry-Pawlak). Przygotowując własny projekt, nie wie tak naprawdę, czy będzie opowiadał w nim bardziej obrazem niż tekstem (Ignatek szuka przyjaciela), czy prawie wyłącznie obrazem (Czarostatki i parodzieje). Może tak to właśnie z książkami jest, że czasem więcej opowiadają słowem, a czasem obrazem.

$\mathrm{W}$ trakcie zbierania tych luźnych dywagacji nie mogłam się wyzwolić z przeczucia, że najbardziej adekwatne do obszaru, po którym się poruszam, jest zarezerwowane już niestety przez pewne gdańskie wydawnictwo określenie: słowoobraz-terytoria. Bo wzajemne związki słowa i obrazu, a także proporcje ilościowe, które ich dotyczą, wyznaczają właśnie różne terytoria - pola badawcze niezmiennie wciągające kolejnych teoretyków.

\section{Literatura}

Hallberg K., 1982, Litteraturvetenskapen och bilderboksforskningen, „Tidskrift för litteraturvetenskap", nr 3-4.

Hallberg K., 2017, Literaturoznawstwo a badania nad książka obrazkową, tłum. H. Dymel-Trzebiatowska [w:] Ksiązka obrazkowa. Wprowadzenie, red. M. Cackowska, H. Dymel-Trzebiatowska, J. Szyłak, Poznań: Instytut Kultury Popularnej.

Nikolajeva M., Scott C., 2006, How Picturebooks Work, New York-London: Routledge.

Schwarcz J.H., 1982, Ways of the Illustrator. Visual Communication in Children's Literature, Chicago: American Library Association.

\section{Materiały źródłowe}

Andersen H.Ch., 1959, Baśnie, Warszawa: Nasza Księgarnia. Andersen H.Ch., 1975, Baśnie, t. 1, Warszawa: Państwowy Instytut Wydawniczy. Potter B., 1969, Krawiec i jego kot, Warszawa: Nasza Księgarnia. Szydłowski S., 1968, Idzie kot, Warszawa: Biuro Wydawnicze „Ruch”. 


\section{Streszczenie}

Zbiór dywagacji na temat pojęcia „książka obrazkowa” przedstawionych z perspektywy badawczej właściwej dla historii sztuki. Rozważania te dotyczą między innymi ścisłości i rodzaju związków między słowem i obrazem w obrębie książek uznawanych za obrazkowe, a według autorki będących po prostu przykładami książek bogato ilustrowanych. W tekście pojawiają się odniesienia do refleksji badaczy zachodnich, między innymi pojęcia ikonotekstu wprowadzonego przez Kristin Hallberg (1982), spostrzeżeń Marii Nikolajevej i Carole Scott w ich opracowaniu How Picturebooks Work (2001) oraz poglądów najbliższego autorce Josepha Schwarcza zawartych w książce Ways of the Illustrator (1982). Znalazło się też tu miejsce dla przykładów oraz krótkich analiz kilku książek polskich i zagranicznych, zarówno autorskich, jak i tych będących efektem współpracy artysty i pisarza.

\section{Słowa kluczowe}

książka ilustrowana, książka obrazkowa, ikonotekst, relacje słowo-obraz

\section{Summary}

\section{Picturebooks perceived by an art historian: obvious issues and second thoughts}

A collection of some digressions focused on the term "picturebook/picture book” which result from art history research perspective. The proposed discussion, among others, deals with the nature of relations between words and images within the books recognised as picturebooks/picture books, and according to the author of the paper, books which are just the examples of richly illustrated books. The text comprises references to Western scholars, including Kristin Hallberg's concept of iconotext (1982), Maria Nikolajeva and Carole Scott's reflections from their study How Picturebooks Work (2001), and Joseph Schwarcz's approach, actually closest to the author's own views, as it was represented in his book entitled Ways of the Illustrator (1982). The paper also includes examples and short analyses of a few Polish as well as foreign books, both created by one artist only or a duo: writer-illustrator.

\section{Keywords}

illustrated book, picturebook, iconotext, word-image relations 
